\title{
Representation and Processing of the Inflected Infinitive in Brazilian Portuguese: an eye-tracking study
}

\section{Representação e processamento dos infinitivos flexionados em português brasileiro: um estudo com rastreamento ocular}

Marcello Modesto

Universidade de São Paulo, São Paulo, São Paulo / Brasil

modesto@usp.br

Marcus Maia

Universidade Federal do Rio de Janeiro, Rio de Janeiro, Rio de Janeiro / Brasil maia@ufrj.br

Abstract: In this paper, we examine the syntactic representation and processing characteristics of null subjects of inflected nonfinite clauses in Brazilian Portuguese (BP). After reviewing some literature on generativesyntax Control and discussing the peculiarities of BP diachrony, we present an eye-tracking experiment which proves that a control interpretation of null subjects of inflected nonfinite clauses is not only psychologically real in BP, but it is actually the preferred option in a task in which a strict comparison with arbitrary PRO is entertained. We then discuss the implications of the experiment to syntactic theory and the analysis of Control and speculate on the role of third factor explanations in the architecture of human language.

Keywords: generative syntax; sentence processing; nonfinite control; inflected infinitives; Brazilian Portuguese; eye-tracking.

Resumo: Este estudo examina a representação sintática e as características de processamento de sujeitos nulos de orações infinitivas flexionadas em português brasileiro (PB). Após revisão de parte da literatura atual sobre a Teoria do Controle e discussão das peculiaridades da diacronia do $\mathrm{PB}$, o artigo apresenta um experimento envolvendo rastreamento ocular 
que comprova que a interpretação controlada do sujeito da infinitiva flexionada é não apenas real psicologicamente, mas também a opção preferida numa tarefa em que se compara a leitura controlada à leitura arbitrária. Discute-se, então, as implicações desse experimento com relação à teoria sintática e à Análise do Controle e especula-se sobre o papel de explicações com base no conceito de terceiro fator na arquitetura da linguagem humana.

Palavras-chave: sintaxe gerativa; processamento de frases; controle não finito; infinitivos flexionados; português brasileiro; rastreamento ocular.

Recebido em: 7 de dezembro de 2017.

Aprovado em: 17 de fevereiro de 2017.

\section{Introduction: Brazilian Portuguese and nonfinite inflection}

The purpose of this study is to investigate the syntactic representation and the psycholinguistic processing of different readings (controlled, arbitrary and referential) of null subjects of inflected nonfinite complement clauses in Brazilian Portuguese (BP). Portuguese (both the European and the Brazilian varieties) is known for having nonfinite inflection (cf. SILVA NETTO, 1950; MAURER, 1968; QUICOLI, 1996; LEMLE, 1984; NEGRÃO, 1986; RAPOSO, 1987, 1989; LIGHTFOOT, 1991; AMBAR, 1994, 1998; MADEIRA, 1994, SITARIDOU, 2002; MILLER, 2002; SCIDA, 2004; NUNES, 2008; MODESTO, 2011, 2016a). However, nonfinite inflection has remained an under-researched characteristic of the language (especially w.r.t. the Brazilian variety) until Modesto (2010) discussed partial control with nonfinite inflection in BP. Modesto's article fed a lot of research on (partial) control and restructuring (LANDAU, 2013, 2015; GRANO, 2012, 2015; WURMBRAND, 2015; MODESTO, 2016a, 2016b) and motivated a return to the study of nonfinite inflection in EP (cf. SHEEHAN, 2014, 2016; GONÇALVES; SANTOS; DUARTE, 2014). In fact, such latter works attested the judgment-data used in Modesto (2010), i.e. the use of nonfinite inflection giving rise to partial control interpretations, in spoken EP and substandard EP. Yet, Modesto's work has been received by some Brazilian linguists with skepticism. 
The views advocated and experimentally confirmed in this work (i.e. that nonfinite inflection is used in BP and that its normal interpretation in complement clauses is a controlled one) contrast sharply with the views expressed in Rodrigues and Hornstein (2013). In fact, Modesto (2010) was a reply to Boeckx and Hornstein (2006), which used data from Rodrigues (2004) to show that a theory of control involving syntactic movement (as in HORNSTEIN, 1999) could not explain several facts about BP syntax. However, as argued by Modesto (2010) (and later in 2016a), Rodrigues' data was both problematic and incomplete, because it did not include data on nonfinite inflection. When taken into consideration, nonfinite inflection presents compelling evidence against the hypothesis that the Movement Theory of Control (MTC) could properly explain all the uses of null subjects of finite and nonfinite clauses in BP. Since part of the theoretical discussion between Modesto and the MTC proponents involved different grammaticality judgments of the relevant data, we have created an eyetracking experiment that can indicate to us the degree of acceptability (or surprise) of inflected infinitives used in three distinct manners (i.e. having distinct antecedents) by BP speakers (college students in Rio de Janeiro). The experiment presented and discussed in section 3 below partially confirms Modesto's (2010, 2016a) claims that Brazilians are not surprised with inflected infinitives in complement clauses and have no problem assigning a control reading to a null category in subject position of an inflected nonfinite complement clause. The referential reading, in which a distant binder is taken as the antecedent of the null category, was thought to be ungrammatical; but the arbitrary interpretation was considered acceptable by Modesto. The examples below seem to indicate that Modesto was correct; however, when tested, referential readings were read faster than arbitrary readings, counter-intuitively:

(1) a. Depois que as crianças foram encontradas, after that the children were found

o casal percebeu terem feito besteira.

the couple realized have.INF.PL done mistake

'After the children were found, the couple concluded that they made/had made a mistake.' 
b. Depois da prefeitura podar as árvores, After the city.hall prune the trees o casal percebeu terem feito besteira. the couple realized have.INF.PL done mistake 'After the city hall pruned the trees, the couple concluded that they made/had made a mistake.'

Example (1a) has a preferable interpretation in which the couple realized that letting the children into the woods (for instance) was a mistake they made. That is the control interpretation. Would it be possible to have the interpretation in which the couple realized that the children made a mistake? That would be the referential interpretation. Finally, it would be possible to have an interpretation in which the couple realized that some arbitrarily defined group of people made a mistake. That reading is easier to get in $(1 \mathrm{~b})$ : after the city hall people pruned the trees we realized they had made a mistake; but it is also possible in (1a), even though it is not the preferred interpretation: after the children were found, the couple realized that someone made a mistake. We will come back to discussing these readings when analyzing the experimental data, in section 4.

The relevance of nonfinite inflection data was harshly criticized by Rodrigues and Hornstein (2013). For clarity, we provide here a concise recap of the dispute. To make his case against movement analyses of control, including the MTC, Modesto (2010) used examples of nonfinite inflection giving rise to partial control (PC) interpretations. Such constructions are assumedly rare in speech, but PC is not the only context of use of inflected infinitives in BP, and not the most common either. Other contexts of use are several kinds of adjunct clauses, subjective clauses and complement clauses of several classes of predicates and nominals (see MODESTO, 2016a for a fuller description). The number of contexts that either allow or require nonfinite inflection is so high as to make nonfinite inflection a salient characteristic of BP, as already noted by Lightfoot (1991, p. 99-102; a.o.). Rodrigues and Hornstein (2013, R\&H from now on), on the other hand, consider the use of inflected infinitives to be "scarce" and not a feature of Brazilian's internal grammar (or core 
grammar), but something learnt in school. ${ }^{1}$ However, concepts like core and peripheric grammar are muddy, at best. One thing that could be considered peripheric (if the concept could be made clear) in BP spoken grammar is the use of $3^{\text {rd }}$ person accusative clitics, a kind of relic, not really used except when one is putting on airs or being very formal in their speech. Third person accusative clitics, which exist in modern EP, are normally not used in spoken BP, having been substituted by full (nonclitic) nominative pronouns or by null objects. ${ }^{2}$ Although we Brazilians learn (in school or when reading literature) how to use those clitics, we almost never use them. When we do use them, they have a clear bookish ring to them. That is not the case with inflected infinitives. At all. Inflection in BP may not be a requirement for every speaker, but it definitely is a grammatical possibility for all speakers. Inflection (nonfinite and finite) is still an active ingredient of BP grammar, or in other words, still belongs to $\mathrm{BP}$ as a linguistic system (an I-language). In a sense, $\mathrm{R} \& \mathrm{H}$ equate nonfinite inflection to $3 p$. accusative clitics, because both would be the product of schooling and reading. However, nonfinite inflection is nothing like accusative clitics in BP: whereas the use of nominative-like full pronouns in accusative position has become the social norm (see example (2a)), even among educated people, $(2 \mathrm{~b})$ on the other hand is frowned upon, since it involves lack of subject-verb agreement, something that has been preserved in the speech of most BP speakers (especially in the big cities, by white people, etc.). It does not matter if the clause is finite

${ }^{1}$ R\&H cite Pires and Rothman (2010) as saying that "the majority of Brazilian Portuguese speakers do not acquire inflected infinitives via an early native acquisition process but rather via late exposure to the standard dialect at school." However, Rothman, Duarte, Pires and Santos $(2013$, p. 7) say textually that there are "standard BP speakers": "inflected infinitives [...] are also found in adult BP, something expected if they correspond to a property of standard BP and if some families are speakers of the standard variety or switch between their colloquial dialect and standard BP (this might indeed explain the production of one inflected infinitive at 3;7 by A.C)." Although Rothman, Duarte, Pires and Santos do say that inflected infinitives are "limited" in the quote above, it is unclear in what sense. In the sense that only part of the population uses the paradigm of nonfinite inflection, then yes, the use of inflected infinitives is limited (to that population). However, the use of inflected infinitives (by that population that uses them) is not limited in any sense.

${ }^{2}$ See Cyrino and Lopes (2016) and Cyrino (2001) for description of usage and analyses of null objects in BP. 
or nonfinite, BP seems to require subject-verb agreement. Therefore, Brazilians do hear infinitives inflecting all the time at work, in television, radio and the internet, whether they use the inflection themselves or not. Brazilian speakers normally accept as grammatical both versions (b-c) below, and react to them in different manners, given their sociolinguistic background (as discussed in section 2 below). More inflecting speakers will tend to accept (2c) better than (2b), less inflecting speakers will favor (2b) over (2c).

(2) a. Eu vi ela ontem.

I saw her yesterday

'I saw her yesterday.'

b. Eu fico contente de vocês ficar aqui.

I stay happy of you.PL stay.INF. Ø here.

'I am glad you guys stay here/are staying here.'

c. Eu fico contente de vocês ficarem aqui.

I stay happy of you.PL stay.INF.PL here.

'I am glad you guys stay here/are staying here.'

R\&H's argumentation departs from the fact that nonfinite inflection is not present in the speech of a number of Brazilian speakers, which would then make it a syntactic relic, similarly to third person accusative clitics. However, R\&H depart from a wrong premise in supposing that BP, considered as an I-language, equals "popular BP", the norm spoken in rural areas of Brazil (see GUY, 1981). ${ }^{3}$ In reality, the fact that there are variants of BP in which nonfinite inflection has no phonological realization may be of no consequence for linguistic analysis. As seen above, (2b-c) have a complementary sociolinguistic behavior: there are speakers who tend to accept the variant with inflection $(2 \mathrm{c})$ better than the one without; and there are speakers, on the other hand, who tend to accept/produce the variant with no inflection (2b). Socio-political and historical facts in Brazil lead one to expect there to be a group of Brazilian speakers to which there would be no difference in grammaticality between

${ }^{3}$ See also section 2 , where the terms "popular" and "standard" are discussed. 
(2b-c), just restrictions of sociolinguistic nature in their use (formality, etc.) related to the social norm. What matters is that, whether inflecting the verb or not, all BP speakers license overt subjects in the same nonfinite contexts (as shown in (2) and (3)), which suggests they have the same grammar. So, contrary to what R\&H assumed, it is not the case that BP speakers have an internalized system with no nonfinite inflection; it is actually the case that all BP have nonfinite agreement, though some speakers have null or zero morphemes to mark such inflection. At least, that would be the simplest explanation for the licensing of overt subjects in contexts like (3b). The form in (3b) is socially stigmatized, which motivates the use of ( $3 a$ ) even in colloquial registers which, again, leads to the conclusion that sentences like (3a) are very common in BP. In fact, many sociolinguists are pointing out an increase in the use of (verbal and nominal) inflection in the last decades in Brazil (cf. LUCCHESI, 2012; OUSHIRO, 2015; SCHERRE; NARO, 2006).

(3) a. Eu prefiro elas ficarem aqui comigo do que lá com o pai.

I prefer they be.INF.PL here with.me of than there with the father

'I'd rather they stay here with me than with their father.'

b. Eu prefiro elas ficar aqui comigo do que lá com o pai.

I prefer they be.INF. $\varnothing$ here with.me of than there with the father

'I'd rather they stay here with me than with their father.'

Overt inflection is not necessary in BP to license overt nominative nonfinite subjects, which means that all speakers (those who use overt inflection more than do not, and those who do not use overt inflection more frequently than they do) have the same internalized grammar, even though there is a lot of social variance. It is then paramount to investigate how inflection is actually used in BP. In what follows, we will be concerned with investigating which syntactic null category occupies the subject position of nonfinite inflected complement clauses in BP and EP. The possible analyses are described, in traditional generative-syntax terms, in (4) below. The pro analysis (4a) takes nonfinite inflection as able to license and identify a null pronominal with independent reference (as well as overt DPs). Therefore, the null subject position may refer to a distant (in terms of c-command) antecedent, or even to have no syntactic binder at all. This analysis seems to account for the behavior of complements of 
propositional predicates such as sugerir (to suggest), pensar (to think), acreditar (to believe) in EP, (cf. RAPOSO, 1987; LANDAU, 2015; SHEEHAN, 2016) and the corresponding examples in (5).

The PRO analysis, in (4b), however PRO may be analyzed, takes subjects of inflected nonfinite verbs to be controlled (by normal rules of syntactic construal). Such analysis would be suitable to explain the interpretations of the null subject in the complement of desiderative predicates in EP (per SHEEHAN, 2016), and in the complement of any partial control predicate in BP (per MODESTO, 2010), see examples in (6). Regarding BP, the subject of an inflected nonfinite complement is either controlled (when null) or overt. ${ }^{4}$

Finally, the proarb analysis (4c) would explain the interpretation of null subjects with arbitrary interpretation, such as the ones in the examples in (7). According to $\mathrm{R} \& \mathrm{H}$, the subject of nonfinite clauses in BP would be either like (4a) or (4c), whereas Modesto (2010, 2016a) argues that only (4b) and (4c) are possible in spoken BP. Our experiment shows that structure (4b) is definitely grammatical in BP. It also shows, surprisingly, that the referential reading is less problematic than the arbitrary reading. We will propose a syntactic explanation for that in section 4 below.

(4) a. $\mathrm{DP}_{1}$ control predicate $\left[\mathrm{CP}_{\mathrm{CP}} \operatorname{pro}_{2} \mathrm{~T}\right.$-tense, + agr $\left.\mathrm{v}\right]$

b. $\mathrm{DP}_{1}$ control predicate $\left[\mathrm{CP}_{\mathrm{CP}} \mathrm{PRO}_{1} \mathrm{~T}\right.$-tense, + agr $\left.\mathrm{v}\right]$

c. $\mathrm{DP}_{1}$ control predicate $\left[\mathrm{CP}_{\mathrm{CP}}\right.$ pro $_{\text {arb }} \mathrm{T}$-tense, + agr $\left.\mathrm{v}\right]$

(5) a. \%A tua tia1 sugeriu pro $_{2}$ encontrarmo-nos, mas sem ela para atrapalhar. the your aunt suggested meet.INF.1 PL REFL but without her to get.in.the.way 'Your aunt suggested that we meet without her getting in the way.'

b. Eu penso/lamento [terem (os deputados) trabalhado pouco]. I think/regret.1sG have.INF.3PL the deputies worked little 'I believe/regret the deputies to have worked very little.'

\footnotetext{
${ }^{4}$ As pointed out by Sheehan 2016, there has been a growing understanding that, in many languages, overt subjects alternate with controlled null subjects in the same syntactic contexts (cf. LANDAU, 2000; SUNDARESAN; MCFADDEN, 2009; SUNDARESAN, 2014; McFADDEN; SUNDARESAN, 2014). This is to be expected, since the controlled subject does receive Case (cf. LANDAU, 2006, 2008; SIGURĐSSON, 2008; BOBALJIK; LANDAU, 2009).
} 
(6) a. A tua tia1 preferia PRO encontrarmo-nos2 sozinhos. the your aunt preferred meet.INF.1 PL REFL alone 'Your aunt preferred that we met alone.'

b. A presidente preferiu PRO nos encontrarmos outro dia. the president preferred REFL meet.INF.1PL another day 'The president preferred for us to meet another day.'

c. *A presidente preferiu PRO nos encontrarmos sem ela. ${ }^{5}$ the president preferred REFL meet.INF.1PL without her 'The president preferred for us to meet without her.'

(7) a. O Luiz1 pensou de proarb terminarem o projeto sem ele1. the Luiz thought about finish.INF.3PL the project without him 'Luiz considered letting people finish the project without him.'

b. O Luiz 1 pensou das meninas irem viajar (sem ele $)_{1}$. the Luiz thought of.the girls go.INF.3PL travel.INF (without him) 'Luiz thought about the girls travelling together (without him).'

BP cannot resort to structure (4a), that much is clear. That is logically deduced by the fact that null subjects may not have independent reference in BP even in finite clauses, so, obviously, nor in nonfinite clauses (cf. MOREIRA DA SILVA, 1984; FIGUEIREDO SILVA, 1994; DUARTE, 1995; NEGRÃO, 1999; GALVES, 1993, 2001; MODESTO, 2000a, 2000b; the collection of articles in ROBERTS; KATO, 1993; and KATO; NEGR ÃO, 2000); so, the fact that R\&H consider structure (2a) to be possible in BP is puzzling, since Rodrigues (2004) had also concluded that there is no referential pro in BP, in consonance with the studies listed above.

As for (4c), it is true that some inflected nonfinite clause's subjects are interpreted arbitrarily, so Modesto (2010) treats (4c) as a possible structure. In the example (8a), below, for instance, the arbitrary reading is forced, since a control interpretation would cause a principle

\footnotetext{
${ }^{5}$ What may occur is "A presidente preferiu nós nos encontrarmos sem ela", with a full referential pronoun occupying the subject position of the nonfinite clause.
} 
$\mathrm{B}$ violation (the pronoun in object position would be bound by the controlled subject). What Modesto (2010) claimed is that, in BP, in absence of any syntactic constrain, the first interpretation of (8b) is a control interpretation, ${ }^{6}$ not an arbitrary one (though that reading may be possible too, see CAVALCANTE, 2006; CAVALCANTE; DUARTE, 2009 on the use of arbitrary overt subjects in BP). To investigate this intuition, we set up an eye-tracking reading experiment in which BP speakers, after reading a clause like $(8 \mathrm{~b})$ were asked to say who has proven the theorem. The results indicate that Modesto's intuitions were correct. Sentences like $(8 \mathrm{~b})$ with a control interpretation are read faster and require less regressive eye movement than similar sentences with arbitrary interpretation.

(8) a. O João acredita gostarem dele.

the João believes like.INF.3PL of.him

'João believes that people like him.'

b. O João acredita terem provado o teorema. the João believes have.INF.3PL proved the theorem 'João believes that they proved the theorem.'

In a recent addition to the debate, Sheehan (2016) shows that EP speakers may be divided between those who take the sentences in (6) to have the representation in (4a), showing obviation effects (cf. SITARIDOU, 2007), and those who use a control structure (4b) for the same sentences. The existence of such Brazilianized EP speakers could be the result of contact between the two varieties or it may indicate a general tendency of Portuguese in treating null subjects of inflected infinitives as controlled subjects. Another run of our eye-tracking experiment with EP speakers should shed some light on what syntactic category occupies the subject of nonfinite clauses for those speakers.

\footnotetext{
${ }^{6}$ One of the anonymous reviewers, at this points, asks why there is no principle B violation here (in (8b)). The answer is contradictorily both simple and complicated. The answer is: because there is no pronoun there to violate principle $\mathrm{B}$. What is there is a PRO (in that reading), not a pro. So now one would ask us what is PRO? That is the complicated part of the answer (see LANDAU, 2013, 2015).
} 
Before turning to the experiment, the following section reviews some technical terms and concepts that are at the source of $\mathrm{R} \& \mathrm{H}$ misunderstanding, that BP is equal to Popular BP. Such a misconception leads them to three unwarranted claims: that inflected infinitives are scarce (in the speech of Brazilian speakers); that their use is regulated by normative grammar; and, that the paradigm of nonfinite inflection is not part of the internalized grammar of Brazilian speakers. The first claim is an empirical matter and interviews eliciting that kind of data are already underway at Universidade Federal do Rio de Janeiro, UFRJ (though a simple google search is already very telling). The second and third claims are obviously false (by speaker's intuition) and are tested (and disproven) in our experiment. Then, section 4 offers some theoretical discussion and interpretation of the data, as well as our concluding remarks.

\section{What is BP after all?}

What is any natural language? What kind of object is a language? The chomskyan tradition has answered those questions in these terms: a language $\mathrm{L}_{1}$ is a mental state produced by the action of the social group (E-language) on the state $\mathrm{L}_{0}$ of the mind, which then produces $\mathrm{L}_{1}$ through a specialized Language Acquisition Device (CHOMSKY, 1965, p. 32). According to Chomsky in Aspects, in order to study a human language $\mathrm{L}$, say BP, one should focus on "an ideal speaker-listener in a completely homogeneous speech-community who knows its language perfectly" (p. 3, our italics). The fact is that no such homogeneous community exists in Brazil, so the study of BP within generative syntax should be a careful one and unfounded assumptions like those in R\&H should not be taken. As always, generative syntacticians should try to unveil the underlying competence of BP speakers that allows them to communicate in such seemingly chaotic linguistic context, as we try to do here.

It is not our intention to review the extensive sociolinguistic literature on (standard) BP and popular BP, but some inescapable concepts will have to be made clear, and some terminology has to be discussed, before any advance can be made in the generative-syntax description of BP (and, in that sense, we build upon GUY, 1981; TARALLO, 1988, 1993; LUCCHESI, 2001, 2004, 2012; LUCCHESI; BAXTER; RIBEIRO, 2009; NARO; SCHERRE, 2007; SCHERRE; NARO, 2006; MATTOS E SILVA, 2004; ILARI; BASSO, 2006; OUSHIRO, 2015; 
FARACO, 2008, 2016). Most importantly, and almost consensually, the sociolinguistic situation in Brazil is described in most works just cited as being polarized between two norms: the norm of middle and upper class (urban white) Brazilians, usually called the "educated" norm (bad term, in our opinion), to which we have been referring as Standard BP; and the norm of working class and rural speakers, the "popular" norm. Such state of affairs, of course, has its roots in Brazilian history of slavery and colonialism. Brazil is believed to have imported more African slaves than any other country. An estimated 4.9 million slaves from Africa came to Brazil during the period from 1550 to 1875 (cf. http://www. slavevoyages.org/). According to Mattos e Silva, "starting from the $18^{\text {th }}$ c. [...], especially in the urban areas that existed, there was a contrast between two possibilities: an Africanized Portuguese and a Europeanized one." (MATTOS E SILVA, 2004, p. 21). ${ }^{7}$

From the $18^{\text {th }} \mathrm{c}$. on, EP started to change (cf. GALVES; GALVES, 1995 ) and those changes solidified in $19^{\text {th }} \mathrm{c}$. EP grammar, which was then adopted by early $20^{\text {th }} \mathrm{c}$. Brazil as its "official language", and, unfortunately, that grammar is still taught in schools in Brazil today. However, the BP spoken in the $18^{\text {th }} \mathrm{c}$. did not change contiguously with EP. (White) BP kept being spoken in Brazil from the $18^{\text {th }} \mathrm{c}$. on with its own characteristics, which culminated on a (white) Portuguese in Brazil today which is not identical to EP nor the Brazilian "official language". Then, in the $20^{\text {th }} \mathrm{c}$., the white-norm and the popular norm intermingled, education reached the lower classes and poor white immigrants (Europeans and Asians who came to Brazil fleeing poverty caused by World Wars I and II) ascended the social ladder "bringing to the heart of the cultured norm some of the structures of popular origin that they acquired in their initial contact with Portuguese." (LUCCHESI; BAXTER; RIBEIRO, 2009, p. 53, our translation). All this has caused the $20^{\text {th }} \mathrm{c}$. pickle Brazilians are in: we speak one language (with two norms) but we learn in our schools a different grammar, as if it were ours. The worst side of the problem is that the so called "educated" norm is more similar, in some respects, to $\mathrm{EP}$, than the "popular" norm, which makes it harder for those speakers to learn the "official dialect" and grade well in university exams. One of such similarities between the "educated" norm and EP (normative grammar)

\footnotetext{
${ }^{7}$ The original is: "a partir do século XVIII [...], sobretudo nas concentrações urbanas que já existiam, o embate se dava entre duas possibilidades: um português africanizado ou um português europeizado.” (MATTOS E SILVA, 2004, p. 21).
} 
is the presence of more verbal and nominal inflection, although nonfinite inflection is used in radically different ways in EP and BP.

As sad as Brazilian social-linguistic situation is, it is inadmissible for us linguists to pretend that such differences do not exist and impose that BP I-grammar is the grammar of the popular speaker (in the sense of only considering data from popular speakers and dishing out all other data as being "peripherical", "not core" features of BP grammar). It is also outrageous to imply that the I-grammar of "educated" speakers is regulated by "school-grammar". As mentioned in the introduction, there are peripheral features in BP grammar, like 3p. accusative clitics, but inflected infinitives are completely different phenomena, with a large distribution of use, which is influenced by speakers' intuitions (cf. MODESTO, 2016a).

As discussed by the authors cited above, there has been much influence in both directions, from "educated" to "popular" and from "popular" to "educated" norms, so we prefer to avoid those terms and urge others to avoid them. Standard and Popular BP are the most used terms in generative circles (again, to refer to the norm spoken by one or another BP speaker, so not to be confused with the "official" language we learn in school). Modesto (2016a) does not use the terms Standard and Popular to avoid misunderstandings and for seeing some residual racism on the term "popular": he then refers to (more) inflecting speakers and less-inflecting speakers; terms that highlight the fact that Popular speakers do inflect sometimes (even infinitives) and that Standard BP speakers sometimes do not inflect (even in finite contexts). Whatever term one may choose, it must be clear that BP data may not be taken from one norm only, because the internalized grammar of Brazilian speakers is acquired within such a polarized sociolinguistic context. Assuming that the inflected infinitive has been "lost" in BP is just bad linguistics.

Given the history of Brazil, and according to the cited authors, actual BP is a continuation of Classical Portuguese, not a new (creole) language and, therefore, the null hypothesis is that nonfinite inflection is still part of BP (qua linguistic system). The study of nonfinite inflection in BP is interesting exactly because BP has lost the property usually referred to as "rich agreement", the property of licensing a null pronoun by force of inflection alone (cf. MODESTO, 2000, among others). The logic behind Modesto's (2010) analysis was to ask what happens in a situation where the colonizer speaks an Italian-type pro-drop language and the other half(at least) of the population speaks a probably creolized version of that language? Either the language becomes a non-pro-drop 
one (in a way, like French did), or it becomes a discourse null-subject language, which is what has happened in Brazil (cf. PONTES, 1987; NEGRÃO; VIOTTI, 2000; MODESTO, 2008). What would happen in nonfinite contexts in the same social linguistic situation? It is highly plausible that null subjects in those contexts would become controlled, since null pronominal subjects are not licensed anymore in the language. Modesto's intuitions, plus collected data, indicated that this is what happened. And, as discussed in the following section, the passage from a pro-drop context to a control context when inflection becomes "weak" is also what is expected by the psycholinguistics literature.

To conclude this section, we believe that the (syntactic) contexts of use of nonfinite inflection in Brazil today and the interpretations of such structures are highly scientific interesting questions, considering Brazilian history and the synchronic social-political situation. We draw attention to the fact that the concepts of controller and antecedent and control and coreference are kept separate here. As discussed in the next section, when different antecedents are chosen as the reference of null categories, the control relation is a special one, for the null category can only have the closest argument as its antecedent in this relation. The notion of 'controller' (as closest antecedent considering c-command) is used in the psycholinguistic literature in exact the same sense it has in generative circles (cf. NICOL; SWINNEY, 1989; BETANCORT; MESEGUER; CARREIRAS, 2004; BETANCORT; CARREIRAS; ACUÑA-FARINA, 2006). The notion of coreference is different than the relation of control. If a null category can be coreferential with several different antecedents, it is most likely not a controlled position. What our experiment shows is that the subject position of nonfinite clauses in BP (inflected or noninflected) is a controlled position in BP when the subject is null. The phenomenon is not 'coreference' of the null category with the matrix subject, it is control, since the more distant antecedent is much harder to process. The experiment below is exactly tailored to show what kind of antecedents are in fact taken by null subjects of inflected infinitives. It shows that most speakers in most contexts tend to take the closest antecedent possible (other antecedents costing more, psychologically). It is therefore concluded that the category occupying the null subject position of an inflected infinitive in $\mathrm{BP}$ is PRO, not pro! The presence of PRO in inflected nonfinite clauses in BP clearly shows that the MTC is the wrong theory to use when dealing with Control (in any language). The corollary is that it cannot be used to explain finite null subjects in BP either. 


\section{The eye-tracking study}

The processing of empty categories in sentence comprehension has been extensively investigated in Psycholinguistics. An important question in this literature has been the assessment of how and when coreferential relations are established between different types of empty categories and their antecedents. Nicol and Swinney (1989) is a seminal paper which examines the role of syntactic constraints on the reactivation and assignment of antecedents to explicit and implicit anaphoric elements during sentence comprehension. The authors review several studies which investigate coreferential assignment between different types of empty categories and their antecedents, concluding that "one consistent finding of recent studies is that reference-dependent sentential elements appear to cause reactivation of the antecedent noun phrases to which they refer" (cf. NICOL; SWINNEY, 1989, p. 6). McElree and Bever (1989) explore further the processing differences between different types of empty categories and conclude that "NP-movement gaps appear to activate their antecedent to a greater extent than PRO gaps" (cf. McELREE; BEVER 1989, p. 34). Fodor (1989) argues that the fact that empty categories of the PRO type are base-generated, that is, do not involve a moved element, makes them especially interesting, since there may be cases in which there are no antecedent warning the empty element before it is encountered.

Frazier, Clifton Jr. and Randall (1983) report a series of experiments testing the processing of empty categories of the PRO type in which they manipulate the main verb of the sentences in terms of their properties of requiring subject or object control. ${ }^{8}$ They measured the reading times for sentences such as (9) and (10) below:

(9) Everyone liked the woman who the little child started PRO to sing those stupid French songs for _ last Christmas.

(10) Everyone liked the woman who the little child forced PRO to sing those stupid French songs last Christmas.

They found that sentences with subject control verbs, such as (9) were read significantly faster than sentences with object control verbs

\footnotetext{
${ }^{8}$ Frazier, Clifton and Randall (1983) also manipulated ambiguity as an additional factor in the study.
} 
as (10). Based on this study the authors proposed the Most Recent Filler Strategy, which postulates that the human sentence processing mechanism prefers the most recent potential filler NP to fill the empty position of the infinitive verb, which is the processing version of syntactic principles like Rosenbaum's (1967) Minimal Distance Principle.

Osterhout and Nicol (1988), on the other hand, investigated the reactivation properties of PRO in a series of priming studies ${ }^{9}$ in sentences as exemplified below, that were composed of a matrix clause containing two potential antecedents and an infinitival clause:

(11) The actress invited the dentist ${ }_{i}$ from the new medical center $\mathrm{PRO}_{\mathrm{i}}$ to go to the party at the mayor's house.

(12) The actress ${ }_{i}$ was invited by the dentist from the new medical center $\mathrm{PRO}_{\mathrm{i}}$ to go to the party at the mayor's house.

In (11), the antecedent of PRO is 'dentist', a recent antecedent; in (12), it is 'actress', a distant antecedent. In their study, Osterhout and Nicol manipulated the position in the sentence in which a prime was launched and they found that when the prime was launched in the area of the last PPs in the sentences, only the actual antecedents were significantly activated: dentist in sentence (11), and actress in sentence (12). Based on these results they argue that the Most Recent Filler Strategy is not invoked in the processing of PRO and that "these results support the hypothesis that all structurally appropriate referents are reactivated" (cf. NICOL; SWINNEY, 1989, p. 17). Despite the controversy about the Most Recent Filer Strategy, both Frazier, Clifton and Randall (1983) and Osterhout and Nicol (1988), as well as McElree and Bever (1989) provide experimental evidence in favor of the so called "psychological reality" of PRO: when encountering PRO, a search for an antecedent in the sentence is activated. Using a priming technique, McElree and Bever (1989) show that the activation properties of PRO are observable, but they are not so strong as the activation properties of NP or Wh-traces. Frazier, Clifton and Randall (1983) measure reading times

\footnotetext{
${ }^{9}$ These priming experiments consisted basically in the oral presentation of sentences, launching a written probe word or prime at specific points of the sentences. Subjects were asked to decide whether or not the probe word was in the sentence. Differences in accuracy rates and average reaction times in probe recognition in different areas of the sentence are then taken to indicate reactivation properties of referents in these areas.
} 
during the reading of subject and object control sentences and propose that PRO prefers the most recent antecedent. Finally, Osterhout and Nicol (1988) argue that not necessarily the most recent, but the structurally appropriate antecedent of PRO is activated. In addition to the self-paced reading and priming techniques, Betancort, Meseguer and Carreiras (2004) study controlled PROs in Spanish, using eye-movement technology. The authors argue that the results of their two eye-tracking experiments show that readers do not seem to delay the selection of an antecedent of PRO. They conclude that " $(. .$.$) when readers arrive at the empty category PRO, they$ begin a search for the antecedent of PRO. This search seems to be carried out quickly..." (cf. BETANCORT; MESEGUER; CARREIRAS, 2004, p.115). Betancort, Carreiras and Acuña-Farina (2006) further manipulate subject and object control verbs as well as adverbial clauses in Spanish in two eye-tracking experiments to show that "coreferential obligatory control is processed fast because it is launched from the same lexical platform that launches all fast-syntactic connections" (cf. BETANCORT; MESEGUER; CARREIRAS, 2004, p. 218).

Empty categories have been a productively investigated topic within the framework of two-stage models of processing, which discriminate between an earlier phase of syntactic parsing and a later phase, where nonstructural information is integrated. Two stage models as Garden Path Theory(GPT) (FRAZIER, 1979; FRAZIER; RAYNER, 1982), among several others) have proposed that the computation of gaps may be resolved as a first resort strategy (cf. FODOR, 1989), prioritizing the computation of grammatical structure over the integration of inferential and contextual information, which would only be accessed at a later integrative phase of comprehension. The present study presupposes the "syntaxfirst" framework of GPT and builds on the evidence that controlled PRO is psychologically real, triggering an antecedent search in the sentence as soon as it is encountered, by comparing the processing of controlled $\mathrm{PRO}$ with the processing of arbitrary PRO in inflected nonfinite clauses in BP. The main questions we wanted to address with our experiment were: (a) Is the search for an antecedent in the sentence the default process in comprehension when there is ambiguity between a controlled and an arbitrary interpretation for PRO? (b) To what extent is the arbitrary interpretation reading of PRO favored, when there is agreement mismatch between a local antecedent for PRO and the verb. (c) To what extent, if any, a referential interpretation of the null nonfinite subject is possible. 
This study monitored the eye gaze of subjects (who were educated, but not necessarily inflecting speakers of BP) as they read sentences in BP made up by a contextualizing subordinate clause, a main clause and a final clause containing an inflected nonfinite clause, on a computer screen. The aim of the experiment was twofold. Firstly, we wanted to investigate the effect of obligatory control contexts on the processing of the sentences vis $\grave{a}$ vis contexts favoring indefinite, arbitrary and referential readings. Secondly, we manipulated number agreement between the subject and the inflected infinitive verb in order to assess whether the singular agreement would totally block a control reading of the sentence or whether a partial control interpretation would still be allowed.

We hypothesized that the latencies of first pass reading measures, the Total Fixation Duration (TFD) would be longer in the noncontrol conditions than in the control conditions, reflecting the higher processing cost of not establishing a local control syntactic relation which should be the default preference in the computation of the sentence. In line with the hypothesis that local control relation should be preferred as default in sentence processing, we also expected that latencies of regressive measures to the contextualizing subordinate sentences should be longer in the noncontrol interpretation conditions than in the control conditions, reflecting the higher cost of inferential processes vis à vis the computation of local grammatical relations. We also predicted that off-line interpretation questions, which were always probing for the referent of PRO in the inflected infinitive clause, should indicate preference for the control interpretation in control conditions in contrast to preference for the noncontrol inferential interpretation in noncontrol conditions, since the off-line interpretation measure should be able to capture post-syntactic integrative processes. ${ }^{10}$

\section{Method}

\section{Participants}

40 undergraduate students at the Federal University of Rio de Janeiro participated in the experiment voluntarily for course credit. They

\footnotetext{
${ }^{10}$ In addition to TFD, the Fixation Count (FC) metric was also measured for each of the relevant areas across the conditions, but did not yield any robust effects and is not reported. Likewise, for the off-line dependent variable, significant effect were found only for the accuracy rates in the interpretation questions, decision times not being informative.
} 
were all native speakers of BP with normal or corrected vision and without any history of reading problems.

\section{Materials and Design}

A total of 16 sets of experimental sentences like those displayed in Table 1 were created. Each sentence was immediately followed by a respective interpretation question probing for the referent of $\mathrm{PRO} /$ pro in the Inflected Infinitive clause. Examples of the corresponding questions for the sentences exemplified in Table 1 are displayed in Table 2. All experimental sentences were composed by an initial subordinate clause followed by a main clause and by a [PRO INFLECTED INFINITIVE CLAUSE]. There were two independent variables crossing in a $2 \times 2$ design, namely, Control context, which had two levels, obligatory control (O) or no control (N), and Number, which could be singular (S) or plural (P). The crossing of these two independent variables, each with two levels, generated four conditions: No-control plural (NP), Obligatory control plural (OP), No control singular (NS), Obligatory control singular (OS). The no control conditions were additionally manipulated in terms of two sub-conditions: 8 sentences had a referential DP in the subordinate clause which could potentially be the controller of the PRO in the Inflected infinitive clause and other 8 sentences did not include such a referential DP in the subordinate clause, forcing an exclusively arbitrary interpretation for the PRO.

Obligatory-control sentences always contained, in the initial subordinate clause, a verb whose cataphoric subject was the subject DP in the main clause. This DP was a semantically plausible subject for all the verbs in the sentence: the subordinate clause verb, the main clause verb and the inflected nonfinite clause verb. The non-control sentences, on the other hand, never allowed the possibility that the main clause subject DP could also be the cataphoric subject of the preceding subordinate clause verb. Non-control sentences always had a DP subject in the main clause which was not likely to be the antecedent for the PRO in the nonfinite clause. In the adjunct clause, non-control sentences either had no semantically plausible controller DP or there was a DP which could plausibly be a distant antecedent for the $\mathrm{PRO} /$ pro in the nonfinite clause. The independent variable 'number' included a level in which the DP subject and the main clause verb agreed in the plural $(\mathrm{P})$ and a level in which the DP subject and the main clause verb agreed in the singular (S). 
Adjunct clause verbs as well as inflected nonfinite verbs were always in the plural. Experimental sentences were distributed in a Latin square design, generating four versions of the experiment. In addition, another 32 sentences with different types of structures were created to serve as fillers. Both for experimental and distractor items, sentence length was controlled to be within 25 to 30 metric syllables range. The 48 sentences (16 experimental and 32 fillers) in each version were pseudo-randomized to be presented in a fixed random order interspersing distracting sentences among the experimental sentences, and guaranteeing that the first and the last two sentences were never experimental sentences.

TABLE 1 - Examples of sentences used in the eye-tracking experiment

\begin{tabular}{|c|c|c|c|c|}
\hline \multicolumn{2}{|c|}{ Cond } & Adjunct clause & Main clause & $\begin{array}{c}\text { Inflected nonfinite } \\
\text { clause }\end{array}$ \\
\hline \multirow{2}{*}{ NP } & $\begin{array}{l}\mathrm{a} \\
\mathrm{r} \\
\mathrm{b}\end{array}$ & $\begin{array}{l}\text { Como os feridos foram } \\
\text { achados logo } \\
\text { As the wounded were } \\
\text { found soon }\end{array}$ & $\begin{array}{l}\text { os repórteres julgaram } \\
\text { the reporters judged }\end{array}$ & $\begin{array}{l}\text { terem salvo muitas } \\
\text { vidas } \\
\text { to have saved many } \\
\text { lives }\end{array}$ \\
\hline & $\begin{array}{l}\mathrm{r} \\
\mathrm{e} \\
\mathrm{f}\end{array}$ & $\begin{array}{l}\text { Só quando os bebês } \\
\text { foram examinados } \\
\text { Only when the babies } \\
\text { were examined }\end{array}$ & $\begin{array}{l}\text { os cuidadores } \\
\text { perceberam } \\
\text { the caretakers realized }\end{array}$ & $\begin{array}{l}\text { terem sujado as } \\
\text { fraldas } \\
\text { to have dirtied the } \\
\text { diapers }\end{array}$ \\
\hline \multicolumn{2}{|c|}{$\mathrm{OP}$} & $\begin{array}{l}\text { Como chegaram logo } \\
\text { ao local da queda } \\
\text { As (they) arrived at } \\
\text { once in the crash area }\end{array}$ & $\begin{array}{l}\text { os bombeiros julgaram } \\
\text { the firefighters judged }\end{array}$ & $\begin{array}{l}\text { terem salvo muitas } \\
\text { vidas } \\
\text { to have saved many } \\
\text { lives }\end{array}$ \\
\hline \multirow[t]{2}{*}{ NS } & $\begin{array}{l}\mathrm{r} \\
\mathrm{b}\end{array}$ & $\begin{array}{l}\text { Como os feridos foram } \\
\text { achados logo } \\
\text { As the wounded were } \\
\text { found soon }\end{array}$ & $\begin{array}{l}\text { o repórter julgou } \\
\text { the reporter judged }\end{array}$ & $\begin{array}{l}\text { terem salvo muitas } \\
\text { vidas } \\
\text { to have saved many } \\
\text { lives }\end{array}$ \\
\hline & $\begin{array}{l}\mathrm{r} \\
\mathrm{e} \\
\mathrm{f}\end{array}$ & $\begin{array}{l}\text { Só quando os bebês } \\
\text { foram examinados } \\
\text { Only when the babies } \\
\text { were examined }\end{array}$ & $\begin{array}{l}\text { o cuidador percebeu } \\
\text { the caretaker realized }\end{array}$ & $\begin{array}{l}\text { terem sujado as } \\
\text { fraldas } \\
\text { to have dirtied the } \\
\text { diapers }\end{array}$ \\
\hline \multicolumn{2}{|c|}{$\mathrm{OS}$} & $\begin{array}{l}\text { Como chegaram logo } \\
\text { ao local da queda } \\
\text { As(they) arrived soon } \\
\text { in the crash area }\end{array}$ & $\begin{array}{l}\text { o bombeiro julgou } \\
\text { the firefighter judged }\end{array}$ & $\begin{array}{l}\text { terem salvo muitas } \\
\text { vidas } \\
\text { to have saved many } \\
\text { lives }\end{array}$ \\
\hline
\end{tabular}


TABLE 2 - Examples of interpretation questions after presentation of each sentence

\begin{tabular}{|c|c|c|}
\hline \multicolumn{2}{|c|}{ Cond } & Interpretation questions \\
\hline \multirow{2}{*}{ NP } & arb & $\begin{array}{lll}\text { Quem salvou muitas vidas? } & \text { (A) os repórteres } & \text { (B) outras pessoas } \\
\text { Who saved many lives? } & \text { (A) the reporters } & \text { (B) other people }\end{array}$ \\
\hline & ref & 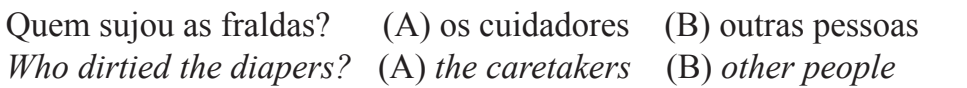 \\
\hline \multicolumn{2}{|c|}{ OP } & 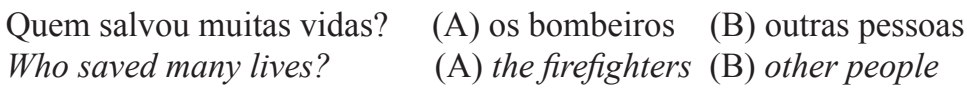 \\
\hline \multirow{2}{*}{ NS } & arb & 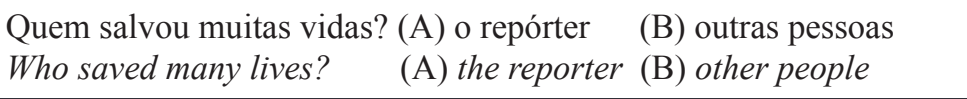 \\
\hline & ref & $\begin{array}{l}\text { Quem sujou as fraldas? (A) o cuidador (B) outras pessoas } \\
\text { Who dirtied the diapers? (A) the caretaker (B) other people }\end{array}$ \\
\hline \multicolumn{2}{|c|}{ OS } & $\begin{array}{lll}\text { Quem salvou muitas vidas? } & \text { (A) o bombeiro } & \text { (B) outras pessoas } \\
\text { Who saved many lives? } & \text { (A) the firefighter } & \text { (B) other people }\end{array}$ \\
\hline
\end{tabular}

\section{Procedures}

A TOBII TX300 eye-tracker monitored subject's eye-movements. Participants viewed the stimuli binocularly on a monitor $65 \mathrm{~cm}$ from their eyes. Sentences were written in Courier New 28pt Font (True Type) and were displayed in a single line. Before the experiment started, subjects read a set of instructions on how to perform the experiment. The instructions told them to read the sentences at a very fast rate, but trying to comprehend the text as well as they could, as they would be asked an interpretation question at the end of each sentence. By pressing the space bar on the keyboard, subjects self-monitored the duration of each sentence on the screen. In order to guarantee a fast reading of the sentences, there was a timeout of 2 seconds, after which the sentence was replaced on the screen by the interpretation question. Participants were asked to try to read the sentence as fast as they could and press the keyboard bar before the timeout. Therefore, after reading the sentence, subjects typically would press the bar before the timeout, in order to call another screen which contained a question with two possible answers, each preceded by (A) and (B) and subjects were instructed to press an (A) or a (B) button in the keyboard. If subjects delayed pressing the bar, 
the screen with the interpretation question would appear automatically after two seconds. There was a 5 second timeout for the interpretation question screen. The experimenter then started a calibration session which consisted in having the subject follow a red ball moving around the screen. If the calibration was successful as indicated by a screen after the calibration session, the experimenter would start a practice session, otherwise a recalibration session would take place. The practice session consisted of three sentences and was observed by the experimenter. If the subject confirmed that he had understood the instructions well and could do the experiment, the instructor would start the experiment and leave the room. A full session would generally last for 25 to 30 minutes.

\section{Results}

For the purpose of the analysis, the texts were segmented in three areas as shown in Table 1: adjunct clause, main clause and inflected nonfinite clause. Results for two different eye-movement measures which displayed robust effects will be reported: (1) Total Fixation Duration (TFD), which refers to the summed durations of all fixations made on each of the three areas and on the whole sentence, including later fixations resulting from regressive movements from subsequent words in the sentence or re-reading the sentence starting at words prior to the target; (2) Second pass duration on the subordinate clause area, which refer to the sum of all refixations directed to that area, either from the left or from the right. The observed differences were statistically evaluated by an ANOVA for subjects (F1). TFDs are indicated in Table 3:

TABLE 3 - TFDs in milliseconds

\begin{tabular}{|c|c|c|c|c|}
\hline Conditions & $\begin{array}{c}\text { Adjunct } \\
\text { clause }\end{array}$ & Main clause & $\begin{array}{c}\text { Inflected nonfinite } \\
\text { clause }\end{array}$ & TOTAL \\
\hline NP & 860 & 418 & 487 & 1765 \\
\hline OP & 692 & 332 & 435 & 1459 \\
\hline NS & 754 & 398 & 474 & 1626 \\
\hline OS & 722 & 376 & 452 & 1550 \\
\hline
\end{tabular}


The $2 \times 2$ ANOVA for subjects crossing the two within subjects factors control and number carried out for the sum of TFDs of each condition shows a highly significant main effect of control $(F(1,159)$ $=213, p<0,000001)$, a marginally significant main effect of number $(\mathrm{F}(1,159)=3,73 \mathrm{p}<0,055374)$ and a highly significant interaction of control*number $(\mathrm{F}(1,159)=98,2 \mathrm{p}<0,000001)$. Pairwise comparisons between the conditions were also performed yielding highly significant results for all relevant crossings: NP x OP $(\mathrm{t}(159)=13,13 \mathrm{p}<0,0001)$, NS x OS $(\mathrm{t}(159)=9,13 \mathrm{p}<0,0001), \mathrm{NP} \times \mathrm{NS}(\mathrm{t}(159)=9,14 \mathrm{p}<0,0001)$ and OP $x$ OS $(\mathrm{t}(159)=4,79 \mathrm{p}<0,0001)$.

The area of the inflected nonfinite clause was also submitted to a 2x2 ANOVA by subjects, showing a highly significant main effect of control $(\mathrm{F}(1,159)=83,0 \mathrm{p}<0,000001)$, a nonsignificant main effect of number $(\mathrm{F}(1,159)=0,218 \mathrm{p}<0,641306)$, and a significant interaction of control*number $(\mathrm{F}(1,159)=11,1 \mathrm{p}<0,001081)$. Pairwise comparisons yielded significant results for NP x OP $(\mathrm{t}(159)=7,74 \mathrm{p}<0,0001)$, NS x OS $(\mathrm{t}(159)=4,30 \mathrm{p}<0,0001)$, OP $\times$ OS $(\mathrm{t}(159)=3,30 \mathrm{p}<0,0012)$, but there was no significance in the comparison between NP $x$ NS $(\mathrm{t}(159)=1,74$ $\mathrm{p}<0,0832$ ).

An ANOVA by subjects was also carried out in the region of the main clause and showed a highly significant main effect of control $(\mathrm{F}(1,159)=190 \mathrm{p}<0,000001)$, a significant main effect of number $(\mathrm{F}(1,159)=9,53 \mathrm{p}<0,002390)$ and a highly significant interaction of control*number $(\mathrm{F}(1,159)=74,4 \mathrm{p}<0,000001)$. Pairwise comparisons yielded significant results for NP x OP $(\mathrm{t}(159)=13,89 \mathrm{p}<0,0001)$, NS $x \operatorname{OS}(\mathrm{t}(159)=4,93 \mathrm{p}<0,0001), \mathrm{NP} x \mathrm{NS}(\mathrm{t}(159)=3,24 \mathrm{p}<0,0014)$ and OP $x$ OS $(\mathrm{t}(159)=11,04 \mathrm{p}<0,0001)$.

First and Second pass fixation durations on the subordinate clause area were also obtained for all conditions and are shown in Table 4.

TABLE 4 - Second pass fixation durations on subordinate clause

\begin{tabular}{|c|c|c|c|}
\hline Condition & $1^{\text {st }}$ pass & $2^{\text {nd }}$ pass & Total \\
\hline NP & 560 & 300 & 860 \\
\hline OP & 558 & 134 & 692 \\
\hline NS & 566 & 188 & 754 \\
\hline OS & 556 & 166 & 722 \\
\hline
\end{tabular}


First pass fixation durations did not exhibit any significant differences in 2x2 ANOVA by subjects neither for main effect of control $(\mathrm{F}(1,159)=1,27 \mathrm{p}<0,261362)$, nor for main effect of number $(\mathrm{F}(1,159)$ $=0,034 \mathrm{p}<0,853785)$. No significant interaction was observed between the factors $(\mathrm{F}(1,159)=0,641 \mathrm{p}<0,424381)$. As expected, there was no difference in pairwise t-tests between the conditions.

Second pass fixation durations on the subordinate clause, on the other hand, displayed significant differences in the 2x2 ANOVA by subjects. There was a highly significant main effect of control $(\mathrm{F}(1,159)=2570 \mathrm{p}<0,000001)$ and a highly significant main effect of number $(\mathrm{F}(1,159)=539 \mathrm{p}<0,000001)$. Pairwise comparisons were also significant for all relevant crossings, in the expected directions. NP $\mathrm{x}$ OP $(\mathrm{t}(159)=44,54 \mathrm{p}<0,0001), \mathrm{NS} \times$ OS $(\mathrm{t}(159)=10,61 \mathrm{p}<0,0001), \mathrm{NP}$ $x$ NS $(\mathrm{t}(159)=32,40 \mathrm{p}<0,0001)$ and OP $x$ OS $(\mathrm{t}(159)=13,45 \mathrm{p}<0,0001)$

A subanalysis comparing the two sub-conditions of the nocontrol condition was also performed to establish any possible effects of referentiality. As explained in the Materials \& Design section above, 8 sentences had a referential DP in the subordinate clause which could potentially be the controller of the PRO in the final clause and other 8 sentences did not include such a referential DP in the subordinate clause, forcing an arbitrary interpretation for the PRO. TFDs for the whole sentences, considering these sub conditions of the no control conditions are indicated in Table 5.

TABLE 5 - TFDs for sub conditions of $\mathrm{N}$ condition

\begin{tabular}{|c|c|c|c|}
\hline NP REF & NP ARB & NS REF & NS ARB \\
\hline 1724 & 1806 & 1584 & 1667 \\
\hline
\end{tabular}

The subject $2 \times 2$ ANOVA showed a highly significant referentiality effect $(\mathrm{F}(1,79)=29,3 \mathrm{p}<0,000001)$ and a highly significant main effect of number $(\mathrm{F}(1,79)=62,4 \mathrm{p}<0,000001)$, but no interaction between the two factors $(\mathrm{F}(1,79)=0,001 \mathrm{p}<0,996830)$. The relevant pairwise t-tests also yielded significant results in the expected directions. NS REF $x$ NS ARB indicated that singular sentences with a potential controller referential DP in the adjunct clause were read significantly faster than singular sentences which did not include such a potential controller referential DP $(\mathrm{t}(79)=5,63 \mathrm{p}<0,0001)$. Likewise, NP REF x NP ARB 
indicated that REF plural sentences were significantly faster than ARB plural sentences $(\mathrm{t}(79)=3,48 \mathrm{p}<0,0008)$. NP REF $x$ NS REF also showed a significant difference $(\mathrm{t}(79)=6,64 \mathrm{p}<0,0001)$, as well as NP ARB $x$ NS ARB $(\mathrm{t}(79)=6,26 \mathrm{p}<0,0001)$.

Off-line interpretation questions were computed and expressed in percentages of CONTROL choices ${ }^{11}$. Table 6 indicates the results obtained for all conditions, including the $\mathrm{N}$ conditions referentiality manipulations in arbitrary (arb) or referential (ref) interpretations:

TABLE 6 - Off-line choices for control interpretation (\%)

\begin{tabular}{|c|c|c|c|c|c|c|}
\hline Cond & NP & NP & NS & NS & OP & OS \\
\hline REF & arb & ref & arb & ref & ------ & ----- \\
\hline Cont. INT & $36 \%$ & $28 \%$ & $29 \%$ & $24 \%$ & $83 \%$ & $62 \%$ \\
\hline
\end{tabular}

Chi-square analyses were performed, yielding the following results: OP $\times$ OS $\left(\mathrm{X}^{2}=6,08, \mathrm{p}=0,01\right)$; OP $\times \mathrm{NP}$ arb $\left(\mathrm{X}^{2}=37,1, \mathrm{p}=\right.$ $0,0001 * * *)$; OP $\mathrm{x}$ NP $\operatorname{ref}\left(\mathrm{X}^{2}=54,5, \mathrm{p}=0,0001 * * *\right)$; NP arb x NP ref $\left(\mathrm{X}^{2}=2,0, \mathrm{p}=0,15^{\mathrm{ns}}\right) ; \mathrm{OS} \times \mathrm{NS}$ arb $\left(\mathrm{X}^{2}=23,9, \mathrm{p}=0,0001^{* * *}\right)$; OS x NS $\operatorname{ref}\left(X^{2}=33,5, p=0,0001^{* * *}\right) ; N S$ arb $x$ NS ref $\left(X^{2}=0,94, p=0,33^{\text {ns }}\right) ; N P$ $\operatorname{arb} x$ NS $\operatorname{arb}\left(X^{2}=1,5, p=0,21^{\mathrm{ns}}\right) ; \mathrm{NP} \operatorname{ref} \mathrm{x} \operatorname{NS} \operatorname{ref}\left(\mathrm{X}^{2}=0,61, \mathrm{p}=0,43^{\mathrm{ns}}\right)$.

\section{Discussion}

The effects obtained for the sum of TFDs of each condition showed that readers took longer to read the noncontrol conditions than to read the control conditions. This overall result already gives us a first answer to our question about the default preference when comparing the processing of controlled PRO with the processing of arbitrary PRO, in inflected nonfinite clauses in BP. When it is possible to establish a local control syntactic relation, the sentence is processed faster than in the indefinite or arbitrary reading cases. In line with Betancort, Meseguer and Carreiras (2004), when readers arrive at the empty category PRO, they begin a search for the antecedent of PRO. The simplest search of

\footnotetext{
${ }^{11}$ Average response times were not significantly different in any of the comparisons between conditions and are not reported.
} 
all takes place in the OP condition in which the subject DP in the main clause is both the cataphoric subject of the subordinate clause verb and of the inflected infinitive verb. Accordingly, the OP condition receives the highest rate of control interpretation when compared to all other conditions. The second fastest reading is OS, the PC condition, in which there is a number mismatch between the main clause subject and both the verbs of the subordinate clause and of the inflected infinitive clause. In this condition, the semantic/pragmatic fit between the main clause subject DP and the inflected infinitive verb allowed for the partial control of the PRO, as established in the off-line measure, which indicated the second highest rate of control interpretation. Again, having a local controller, even if partial, facilitated the PRO coreference search, confirming the preference for a local controller of the PRO as the default process in the resolution of nonfinite clauses. Noncontrol sentences took longer to read than Control or PC sentences, receiving lower rates of control interpretation than control or partial control sentences, as expected. ${ }^{12}$

Total fixation durations of NS sentences are longer than OS sentences and OP sentences, but shorter than NP sentences. Both NP and NS sentences presented a subject DP in the main clause which was not a plausible controller for PRO in the inflected nonfinite clause, opening the way for an arbitrary interpretation. The number mismatch between the subject DP in the main clause and the inflected nonfinite verb should contribute to additionally rule out the control analysis, pushing the reader even more towards the arbitrary analysis. NP sentences, in contrast, establishing plural agreement matching between the subject DP of the main clause and the plural agreement feature of the inflected infinitive verb would create a potential ambiguity between an arbitrary and a control reading for the PRO, leading the reader to fixate longer the sentences in this condition.

As indicated in the last column of Table 3, the total reading durations per condition were distributed as follows: $\mathrm{OP}<\mathrm{OS}<\mathrm{NS}<$

\footnotetext{
${ }^{12}$ Note that in the $\mathrm{N}$ conditions there is still a $24 \%$ to $36 \%$ choice for the control interpretation. As indicated in the statistical analyses, these differences are not significant across the $\mathrm{N}$ conditions, but the very fact that even in the $\mathrm{N}$ conditions a control interpretation is residually entertained can be taken as a further evidence of the default control analysis proposed in this paper.
} 
NP. Having a local controller for the PRO, OP sentences are the easiest to read, as illustrated by the heatmap ${ }^{13}$ of a typical reading, in Figure 1.

FIGURE 1 - OP sentence:

Como chegaram logo ao local da queda, os bombeiros julgaram terem salvo muitas vidas

As they arrived at once in the crash area, the firefighters judged to have saved many lives.

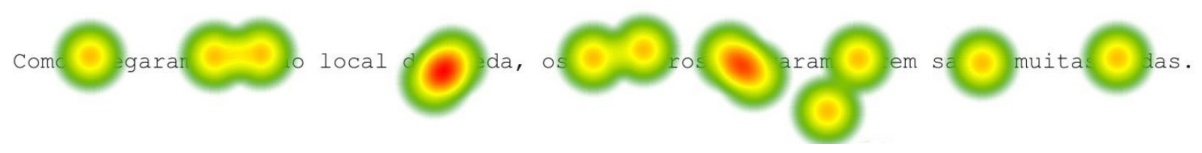

OS sentences take longer to read than OP sentences, as there is a number mismatch between the felicitous subject DP of the main clause and the inflected infinitive verb. However, partial control is still possible and they are resolved in shorter reading times than the $\mathrm{N}$ sentences, which were intended to block the local control interpretation and require more exhausting visual search for a controller for the PRO. Not finding a possible local controller in an $\mathrm{N}$ sentence, readers should invoke the arbitrary reading as a last resort. Figure 2 provides the heatmap obtained during the reading of an OS sentence and Figure 3 exemplifies the reading of an NS sentence.

FIGURE 2 - OS sentence:

Como chegaram logo ao local da queda, o bombeiro julgou terem salvo muitas vidas.

As they arrived at once in the crash area, the firefighter judged to have saved many lives.

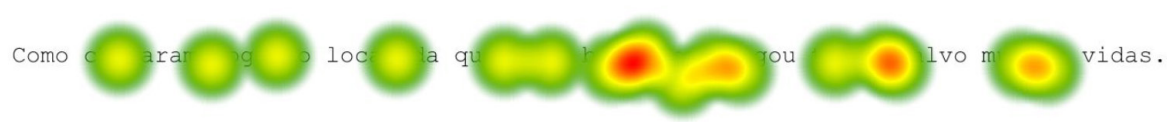

\footnotetext{
${ }^{13}$ A heatmap is a graphical representation of data where the individual values contained in a matrix are represented as colors. The areas where readers looked the most are colored red; the yellow areas indicate fewer views, followed by the least-viewed green areas.
} 
FIGURE 3 - NS ref sentence:

Só quando os bebês foram examinados, o cuidador percebeu terem sujado as fraldas. Only when the babies were examined, the caretaker realized (them) to have dirtied the diapers.

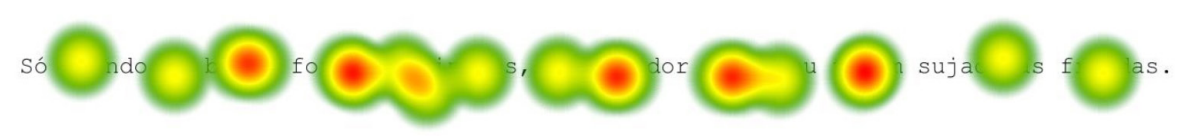

Notice that in Figure 3, the correct interpretation of the null category requires an inferential chain, since in addition to number mismatch, it would not be plausible to analyze the DP o cuidador "the caretaker" as the agent of having dirtied the diapers. In the NSref condition there is a possible controller in the adjunct clause, but not in the NS arb condition exemplified in Figure 4, in which, in the adjunct clause, there is no possible antecedent. Notice that, in Figure 4, the correct interpretation of PRO requires an inferential chain, since in addition to number mismatch, it would not be plausible to analyze the DP the candidate as the agent of being ill intentioned. Additionally, in the subordinate clause there is no possible controller for PRO either. The arbitrary interpretation is invoked only after the first resort search for a local controller is unsuccessful, resulting in even longer fixations during reading.

FIGURE 4 - NS arb sentence:

Quando o concurso foi cancelado, o candidato julgou estarem mal-intencionados. When the selection was cancelled, the candidate judged (them) to be ill intentioned.

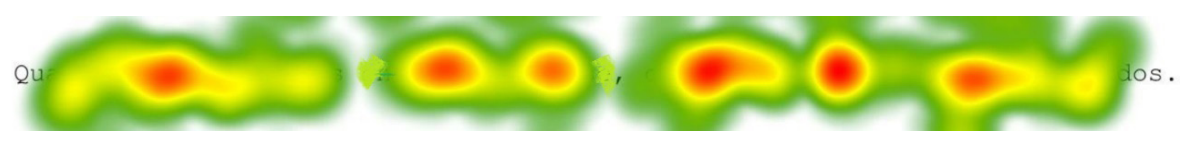

In the NP condition, agreement between the main clause subject DP and the inflected infinitive verb seems to make the search for a local controller even longer, possibly misleadingly allowing for the initial search for a local controller which is then discarded because it is not a felicitous agent, even though matching in formal features. The search proceeds then to find a possible controller in other areas of the sentence. Figure 5 illustrates the heatmap of an NP ref sentence. 


\section{FIGURE 5 - NP ref sentence:}

Quando os terroristas chegaram na base, os pilotos perceberam estarem armados. When the terrorists arrived at the base, the pilots realized (them) to be armed.

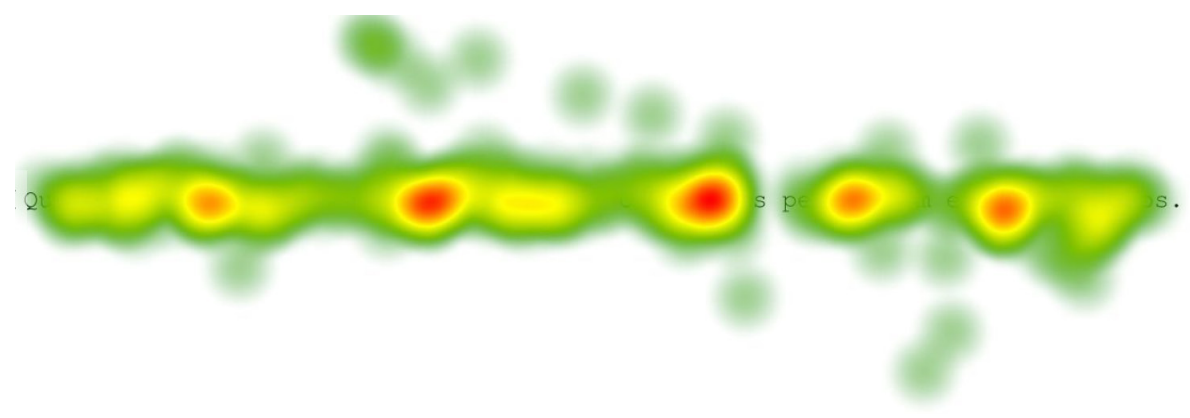

Finally, Figure 6 illustrates the heatmap of an NP arb sentence, which requires the longest average fixations of all conditions, since there is no felicitous DP in the sentence which could be the proper controller for the PRO. The arbitrary interpretation of the-PRO is the costliest.

FIGURE 6 - NP arb sentence:

Quando os dados chegaram na base, os cientistas perceberam estarem em órbita.

When the data arrived at the base, the scientists realized to be in orbit.

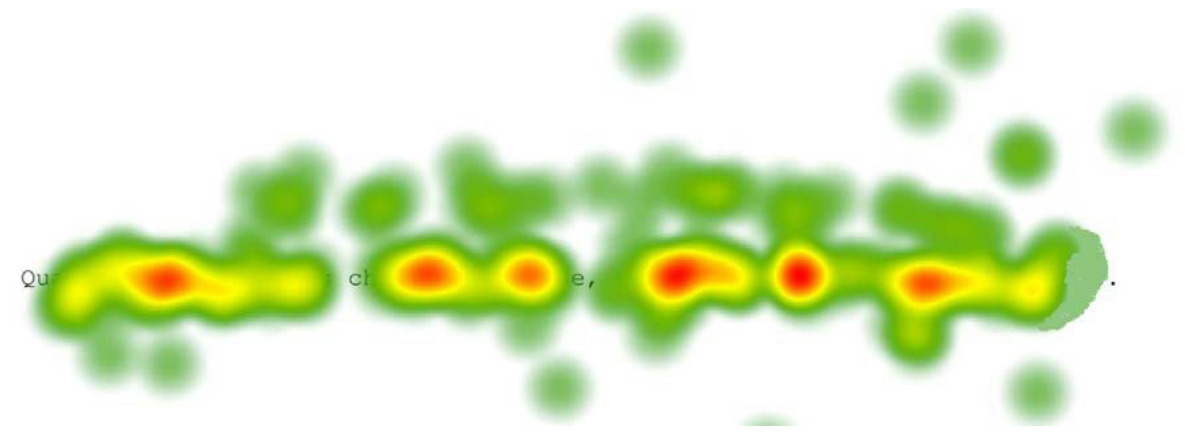

As shown in the Results section, comparative analyses of other areas of the sentences between the four conditions also display main effects of control. Pairwise comparisons between the conditions also indicated interesting significant differences in the areas of the main clause and of the inflected nonfinite clause in the expected direction, attesting that the noncontrol conditions are harder to process than the control conditions. 
Table 4 shows comparative analyses between the total fixation durations during the first pass and the second pass in the area of the subordinate clause. As expected the first pass measures do not exhibit any significant differences between the conditions, since at this point readers had not been exposed to the independent variables. Notice, however, that second pass measures differ in the expected direction: readers exhibited significantly lesser regressions to the adjunct clause in the OP condition, which resolves the PRO coreference in a very straightforward manner than in any other condition. Actually, second pass measures in the subordinate clause confirm the hierarchy established for the TFD of the sentences: $\mathrm{OP}<\mathrm{OS}<\mathrm{NS}<\mathrm{NP}$, indicating that regressions are progressively needed to compute the sentences as they move away from local syntactic control to more arbitrary or ambiguous interpretations, again, in line with the hypothesis that local control relations should be preferred as default in sentence processing.

To conclude, the subanalyses entertained here between the arbitrary $\mathrm{x}$ referential manipulations of the $\mathrm{N}$ sentences also confirm the hypothesis. As shown in Table 5, referential noncontrol sentences are read faster than arbitrary noncontrol sentences, again indicating the preference for local syntactic relations which can resolve coreference more readily and are therefore preferred to inferential processes, as predicted by twostage models of sentence processing, as Garden Path Theory.

\section{Theoretical discussion and conclusions}

As detailed in section 3, in line with several previous psycholinguistic studies, especially work on structural models of sentence processing, which have very consistently established the priority of structural computations over inferential interpretations, the present paper has demonstrated, among other things, the priority of structural processes over inferential interpretations in the processing of PRO in BP: when readers arrive at the empty category $\mathrm{PRO}$, they begin a search for the antecedent of PRO as a default. The most accessible antecedent for the null category in our test-sentences was the subject of the matrix clause and when context and lexical choices allowed that control interpretation, reading of the sentence was easiest. This means that controlled PRO in inflected nonfinite clauses is not only psychologically real in BP, it is actually the preferred option in a task in which a strict comparison with arbitrary PRO is entertained. 
This means that none of the problems raised by $\mathrm{R} \& \mathrm{H}$ are relevant and the data in Modesto (2010) does refute movement analyses of Control. All these assertions should be unpacked here, if we had the space. For now, let us just take notice of how the MTC makes the wrong predictions about BP, when actual data is taken into consideration. Besides the psycholinguistic discussion, we have seen, in section 2 , that nonfinite inflection has been present in the speech of BP speakers (actively, for some speakers; passively for others) for at least three centuries

Given BP's sociolinguistic history and context, it is easy to see how Portuguese is spoken scarcely in the Brazil of the $16^{\text {th }} \mathrm{c}$. (i.e. exclusively at or around the "big" cities that were formed then (Salvador, BA; Pernambuco, PE; Rio de Janeiro, RJ e São Paulo, SP). However, Portuguese becomes the only language acquired by most people born in Brazil from the $18^{\text {th }} \mathrm{c}$. on. Such nativization process lasted only two centuries, speakers learnt their Portuguese from very different sources (white BP vs. black BP). Then in the $20^{\text {th }} \mathrm{c}$., these two variants of BP were mixed and mingled. But there should be no problem since we have been using the same language, after all. It is unimaginable that through the $19^{\text {th }} \mathrm{c}$. white speakers had a much different grammar than black speakers. It would have been impossible for BP to keep the romancetype pro-drop grammar brought here by the $17^{\text {th }}$ and $18^{\text {th }} \mathrm{c}$.-Portuguese people who immigrated, because some (roughly half) of the speakers (slaves and Indians) had no inflection in their system during that time. So already in the $19^{\text {th }} \mathrm{c}$., at least, BP probably was already a non-pro-drop language (to every speaker; no matter how much inflection they used). It is possible that very few conserved the older system, or that some people were bilingual speakers of both varieties of BP at that time (see $\mathrm{KROCH}$, 2001 on grammars in competition). But that is unlikely for nowadays $\mathrm{BP}$, since there is no evidence for two different linguistic systems in Brazil, just a lot of morphological variation. If the conclusions expressed here for the discussion in section 2 are correct, i.e. if all Brazilians have nonfinite inflection whether using it overtly or not, this is very much in accordance with a third factor explanation (cf. CHOMSKY, 2005, as pointed out by one of the anonymous reviewers of this paper) for syntactic data of natural languages. Interestingly, the present work has brought about relevant data for a contemporary challenge in the relatively new domain of Experimental Syntax - the interplay between processing algorithms, Universal Grammar (UG) and the grammar of particular 
languages. Principles of computational efficiency have been analyzed as third factor effects (cf. CHOMSKY, 2005). If the PRO control processing default shown in the present paper can be claimed to be an efficiency processing algorithm it raises interesting architecture issues concerning the interaction of processing and grammar. In this respect, we follow the proposal in Trotkze, Bader and Frazier (2013) that "properties of performance systems can play an important role within the biolinguistic perspective on language by providing third-factor explanations for crucial design features of human language" (TROTKZE; BADER; FRAZIER, 2013, p. 28). Of course, third factor effects must interact with UG principles and with grammatical properties of specific languages, sometimes bringing about tensions when they apply in the derivations, but they probably do not override grammar internal principles, as argued for in Di Sciullo and Aguero (2008) on independent grounds. We intend to keep on this line of research, incorporating EP experimental data and comparing the results with BP.

The problem with that explanation is that $\mathrm{BP}$ continues to be a language with null subjects, even if not a pro-drop language, using a different strategy that does not rely on inflection (like Chinese). Subjects of inflected clauses can still be null in BP, but they now have a controlled interpretation (in most contexts), as the experiment demonstrates. The odd result, however, is that our informants seem to have less trouble getting a non-controlled, referential reading of the null subject than getting an arbitrary reading. Though unproblematic for the psycholinguistics part, this result is tricky to explain syntactically. If BP inflection does not license null pronouns anymore, how are referential readings achieved by BP speakers? A mandatory quasi-topic position in BP, as proposed in Modesto (2008), nicely explains those readings, given a suitable context, as our test-sentences provided. Take (13a) as an example. Its representation would be (13b), with an elided topic:

(13) a. Só quando os bebês foram examinados, o cuidador percebeu terem only when the babies were examined, the caretaker noticed have.INF.3PL sujado as fraldas soiled the diapers

'When the babies were examined, the caretaker noticed that they have soiled the diapers.' 
b. [ [ Só quando os bebês foram examinados] [os bebês ${ }_{i}$ [ o cuidador percebeu $\left[\mathrm{PRO}_{\mathrm{i}}\left[\mathrm{PRO}_{\mathrm{i}}\right.\right.$ terem sujado as fraldas ]]]

The example in (14a), on the other hand, has the structure in (14b).

(14) a. Como chegaram logo ao local da queda,

as arrive.PST.3PL soon to.the place of fall

o bombeiro julgou terem salvo muitas vidas.

the firefighter judged have.INF.3PL saved many lives

'As(they) arrived soon in the crash area, the firefighter judged

to have saved many lives.'

b. [ [ Como chegaram logo ao local da queda] [o bombeiro ${ }_{i}$

[ ec $\mathrm{e}_{\mathrm{i}}$ julgou [ $\mathrm{PRO}_{\mathrm{i}}\left[\mathrm{PRO}_{\mathrm{i}}\right.$ terem salvo muitas vidas ]]]]]

We believe that the empty category in (14c) marked as ec is just a minimal pronoun (as in SZABOLCSI, 2009), the same category that produces control (as in LANDAU, 2015), which gets the values for its features by being bound by "o bombeiro", the firefighter, the closest possible antecedent. PRO itself is a minimal pronoun that climbs to the quasi-topic position, still finds no value for its person feature, which then causes the control phenomenon (all as described in LANDAU, 2015). It can be seen, then, that BP data involving inflected infinitives are unproblematic when the most plausible analysis of control is assumed.

\section{Acknowledgments}

This work is part of the State University of Campinas project "Portuguese in space and time: linguistic contact, grammars in competition and parametric change" (FAPESP 12/06078-9), per the first author and of the CNPq research project "Experimental Syntax and Semantics: timecourse and underspecification in the on-line implementation of grammar" $(\mathrm{CNPq}$ 302989/2015-3), per the second author. We both wish to thank our informants and the students involved in the experiment described here, as well as two anonymous reviewers who made valuable comments on our first draft. All remaining errors are ours, of course. 


\section{References}

AMBAR, M. "Aux-to-COMP" and lexical restrictions on verb movement. In: CINQUE, G.; KOSTER, J.; POLLOCKJ.Y; RIZZI, L.; ZANUTTINI, R. (Org.). Paths towards universal grammar. Amsterdam: John Benjamins, 1994. p. 1-24.

AMBAR, M. Inflected infinitives revisited: Genericity and single event. Canadian Journal of Linguistics, Cambridge University Press, v. 43, p. 5-36, 1998.

BETANCORT, M.; CARREIRAS, M.; ACUÑA-FARINA, C. Processing controlled PROs in Spanish. Cognition, Elsevier, v. 100, p. 217-282, 2006. https://doi.org/10.1016/j.cognition.2005.04.001

BETANCORT, M.; MESEGUER, E.; CARREIRAS, M. The empty category PRO: Processing what cannot be seen". In: CARREIRAS, M.; CLIFTON, C. (Org.). The online study of sentence comprehension: Eyetracking, ERP, and beyond. C. Brighton: Psychology Press, 2004.

BOBALJIK, J.; LANDAU, I. Icelandic Control is not A-movement: The Case from Case. Linguistic Inquiry, MIT Press, v. 40, p. 113-132, 2009. https://doi.org/10.1162/ling.2009.40.1.113

BOECKX, C.; HORNSTEIN, N. The Virtues of Control as Movement. Syntax, Wiley Online Library, v. 9, p. 118-130, 2006.

BOECKX, C.; HORNSTEIN, N.; NUNES, J. Control as movement. Cambridge: Cambridge University Press, 2010. https://doi.org/10.1017/ CBO9780511761997

CAVALCANTE, S. R. O. O uso de SE com infinitivo na história do português: do Português Clássico ao Português Europeu e Brasileiro modernos. 2006. Tese (Doutorado) - Unicamp, Campinas, 2006.

CAVALCANTE, S. R. O.; DUARTE, M. E. L. Sujeitos de referência arbitrária em sentenças infinitivas do português e o parâmetro do sujeito nulo. In: TSIPLAKOU S.; KARYOLEMOU, M.; PAVLOU, P. (Org.). Language Variation - European perspectives II: selected papers from the 4th international conference on language variation in Europe. Amsterdam: John Benjamins, 2009. p. 47-58. 
CHOMSKY. N. Aspects of the theory of syntax. Cambridge: The MIT Press, 1965.

CHOMSKY, N. Three factors in Language Design. Linguistic Inquiry, v. 36: n. 1, p. 1-22, Winter 2005. doi: 10.1162/0024389052993655

CYRINO, S. M. L. O objeto nulo no português do Brasil e no português de Portugal. Revista da ABRALIN, Abralin, v. 25, p. 173-181, 2001.

CYRINO, S. M. L.; LOPES, R. Null objects are ellipsis in Brazilian Portuguese. The Linguistic Review, De Gruyter, v. 33, p. 1-19, 2016.

DI SCIULLO, A.M.; AGUERO, C. The delay of Condition B Effect and its Absence in Certain Languages. Language and Speech, Sage Publications, v. 51, p. 77-100, 2008. https://doi.org/10.1177/00238309 080510010601

DUARTE, M. E. A perda do princípio "evite pronome" no português brasileiro. 1995. Tese (Doutorado) - Unicamp, Campinas, 1995.

FARACO, C. A. Norma culta brasileira: desatando alguns nós. São Paulo: Parábola, 2008.

FARACO, C. A. História sociopolítica da língua portuguesa. São Paulo: Parábola, 2016.

FIGUEIREDO SILVA, M. C. La position sujet en Portugais Brésilien. 1994. Dissertation (Doctoral) - Université de Genève, Genève, 1994.

FODOR, J. D. Empty categories in sentence processing. Language and Cognitive Processes, Taylor \& Francis Online, v. 4, p. 155-209, 1989.

FRAZIER, L. On comprehending sentences: syntactic parsing strategies. 1979. Dissertation (Doctoral) - University of Massachusetts, Connecticut, 1979. [Reproduced by Indiana University Linguistics Club.]

FRAZIER, L.; CLIFTON JR., C.; RANDALL, J. Filling gaps: decision principles and structure in sentence comprehension. Cognition, Elsevier, v. 13, p. 187-222, 1983. https://doi.org/10.1016/0010-0277(83)90022-7

FRAZIER, L.; RAYNER, K. Making and correcting errors during sentence comprehension: Eye movements in the analysis of structurally ambiguous sentences. Cognitive Psychology, Elsevier, v. 14, p. 178-210, 1982. https://doi.org/10.1016/0010-0285(82)90008-1 
GALVES, A.; GALVES, C. A case study of prosody driven language change: from classical to modern EP. 1995. Ms. - UNICAMP-USP, Campinas, 1995. Disponível em: $<$ http://www.1llf.uam.es/ clase/acceso local/prosodydriven.pdf $>$.

GALVES, C. O enfraquecimento da concordância em português brasileiro. In: ROBERTS, I.; KATO, M. A. (Org.). Português Brasileiro, uma viagem diacrônica. Campinas: Editora da Unicamp, 1993. p. 387-408.

GALVES, C. Ensaios sobre as gramáticas do português. Campinas: Editora da Unicamp, 2001.

GONÇALVES, A.; SANTOS, A. L.; DUARTE, I. (Pseudo-)Inflected infinitives and Control as Agree. In: LAHOUSSE, K.; MARZO, S. Romance Languages and Linguistic Theory: Selected papers from 'Going Romance’ Leuven. Amsterdam: John Benjamins, 2014. p. 161-180. https://doi.org/10.1075/rllt.6.08gon

GRANO, T. A. Control and restructuring at the syntax-semantics interface. Dissertation (Doctoral) - University of Chicago, Chicago, 2012.

GRANO, T.A. Control and restructuring. Oxford: Oxford University Press, 2015. https://doi.org/10.1093/acprof:oso/9780198703921.001.0001

GUY, G. R. Linguistic variation in Brazilian Portuguese: Aspects of the phonology, syntax, and language history. 1981. Dissertation (Doctoral) - University of Pennsylvania, Philadelphia, 1981.

HORNSTEIN, N. Movement and Control. Linguistic Inquiry, MIT Press, v. 30, p. 69-96, 1999. https://doi.org/10.1162/002438999553968

ILARI, R.; BASSO, R. O português da gente: a língua que estudamos, a língua que falamos. São Paulo: Ed. Contexto, 2006.

KATO, M.A. Strong and weak pronominals and the null subject parameter. Probus, Berlin, v. 11, n. 1, p. 1-38, 1999. https://doi.org/10.1515/ prbs.1999.11.1.1

KATO, M.; NEGRÃO, E. V. (Org.). Brazilian Portuguese and the null subject parameter. Frankfurt: Vervuert-Iberoamericana, 2000. 
KROCH, A. Syntactic Change. In: BALTIN, M.; COLLINS, C. (Org.). The Handbook of Contemporary Syntactic Theory. Oxford, Mass.: Blackwell Publishers Inc., 2001. p. 699-729. https://doi. org/10.1002/9780470756416.ch22

LANDAU, I. Elements of Control: Structure and meaning in infinitival constructions. Dordrecht: Kluwer, 2000. https://doi.org/10.1007/97894-011-3943-4

LANDAU, I. Severing the Distribution of PRO from Case. Syntax, Wiley Online Library, v. 9, p. 153-170, 2006.

LANDAU, I. Two Routes of Control: Evidence from Case Transmission in Russian. Natural Language and Linguistic Theory, Springer Link, v. 26, p. 877-924, 2008.

LANDAU, I. Control in generative grammar: a research companion. Cambridge: Cambridge University Press, 2013. https://doi.org/10.1017/ CBO9781139061858

LANDAU, I. A two-tiered theory of Control. Cambridge, MA: The MIT Press, 2015. https://doi.org/10.7551/mitpress/9780262028851.001.0001 LEMLE, M. Análise sintática. São Paulo: Ática, 1984.

LIGHTFOOT, D. How to set parameters: Arguments from language change. Cambridge, MA: MIT Press, 1991.

LUCCHESI, D. As duas grandes vertentes da história sociolinguística do Brasil. DELTA, São Paulo, PUC-SP, v. 17, p. 97-130, 2001.

LUCCHESI, D. Sistema, mudança e linguagem: um percurso na história da linguística moderna. São Paulo: Parábola, 2004.

LUCCHESI, D. A concordância verbal e a polarização sociolinguística do Brasil. UFBA, 2012. Unpublished paper.

LUCCHESI, D.; BAXTER, A.; RIBEIRO, I. O Português Afro-Brasileiro. Salvador: EDUFBA, 2009. https://doi.org/10.7476/9788523208752

MADEIRA, A. M. On the Portuguese inflected infinitive. In: XX INCONTRO DI GRAMMATICA GENERATIVA, XX., 1994. Pádua. Teoria del Linguaggio e Analisi Lingüística. Pádua: Unipress, 1994. p. 289-314. 
MATTOS E SILVA, R. V. Uma sócio-história do português brasileiro. São Paulo: Parábola Editora, 2004.

MAURER Jr., T. M. O infinitivo flexionado português. São Paulo: Ed. Nacional; EdUSP, 1968.

McELREE, B.; BEVER, T. G. The psychological reality of linguistically defined gaps. Journal of Psycholinguistic Research, Springer Link, v. 18, p. 21-35, 1989.

McFADDEN, T.; SUNDARESAN, S. Finiteness in South Asian languages: an introduction. Natural Language and Linguistic Theory, Springer Link, v. 32, p. 1-28, 2014.

MILLER, D. G. Nonfinite Structures in Theory and Change. Oxford: Oxford University Press, 2002.

MODESTO, M. On the identification of null arguments. Dissertation (Doctoral) - University of Southern California (USC), Los Angeles, 2000a.

MODESTO, M. Null subjects without "rich" agreement. In: KATO, M. A.; NEGRÃO, E. V. (Org.). Brazilian Portuguese and the null subject parameter. Frankfurt: Vervuert- Iberoamericana, 2000b. p. 147-174.

MODESTO, M. Topic prominence and null subjects. In: BIBERAUER, T. (Org.). The limits of syntactic variation. Amsterdam: John Benjamins Publishing, 2008. p. 375-410. https://doi.org/10.1075/la.132.17mod.

MODESTO, M. What Brazilian Portuguese says about control: remarks on Boeckx \& Hornstein. Syntax, Wiley Online Library, v. 13, n. 1, p. 7896, 2010. https://doi.org/10.1111/j.1467-9612.2009.00136.x

MODESTO, M. Finite control: Where movement goes wrong in Brazilian Portuguese. Journal of Portuguese Linguistics, Lisboa, Ubiquity Press, v. 10, n. 1, p. 3-30. 2011.

MODESTO, M. Inflected infinitives in Brazilian Portuguese and the theory of control. In: GONÇALVES, A. (Org.). Complement Clauses in Portuguese: Syntax and Acquisition. Amsterdam: John Benjamins. 2016a. In press. 
MODESTO, M. Inflected infinitives and restructuring in Brazilian Portuguese. In: KATO, M. A.; ORDÓÑEZ F. (Org.). Morphosyntax of Spanish and Portuguese in Latin America. Oxford: Oxford University Press, 2016b. p. 157-176. https://doi.org/10.1093/acprof:o so/9780190465889.003.0007.

MOREIRA DA SILVA, S. Etudes sur la symétrie et l'asymétrie SUJET/ OBJET dans le Portugais du Brésil. 1984. Dissertation (Doctoral) Université de Paris VIII, Paris, 1984.

NARO, A.; SCHERRE. M. M. P. Origens do português brasileiro. São Paulo: Parábola Editorial, 2007.

NEGRÃO, E. V. Anaphora in Brazilian Portuguese complement structures. Dissertation (Doctoral) - University of Wisconsin, Madison, 1986.

NEGRÃO, E. V. O português brasileiro: uma língua voltada para o discurso. 1999. Tese (Livre-docência) - Universidade de São Paulo, São Paulo, 1999.

NEGRÃO, E. V.; VIOTTI, E. Brazilian Portuguese as a DiscourseOriented Language. In: KATO, M. A.; NEGRÃO, E. V. (Org.). Brazilian Portuguese and the Null Subject Parameter. Frankfurt: VervuertIberoamericana, 2000. p. 105-125.

NICOL, J.; SWINNEY, D. The role of structure in coreference assignment during sentence comprehension. Journal of Psycholinguistic Research, Springer Link, v. 18, p. 5-19, 1989.

NUNES, J. Inherent case as a licensing condition for A-movement: The case of hyper-raising constructions in Brazilian Portuguese. Journal of Portuguese Linguistics, Lisboa, Ubiquity Press, v. 7, n. 2, p. 83-108, 2008.

OSTERHOUT. L.; NICOL, J. The time-course of antecedent activation following empty subjects. 1988. Unpublished manuscript.

OUSHIRO, L. Identidade na Pluralidade. Tese (Doctorado) Universidade de São Paulo, São Paulo, 2015.

PIRES, A.; ROTHMAN, J. Building bridges: Experimental L1 acquisition meets diachronic linguistics. In: GUIJARRO-FUENTES, P.; DOMÍNGUEZ, L. (Org.). New directions in language acquisition: Romance languages in the generative perspective. Newcastle upon Tyne, UK: Cambridge Scholars Publishing, 2010. p. 357-385. 
PONTES, E. O tópico no português do Brasil. Campinas: Pontes, 1987. POSSENTI, S. Por que (não) ensinar gramática na escola. Campinas: Mercado de Letras, 1996.

QUICOLI, A. C. Inflection and parametric variation: Portuguese vs. Spanish. In: FREIDIN, R. (Org.). Current issues in comparative grammar. Amsterdam: Springer, 1996. p. 46-80. https://doi.org/10.1007/978-94009-0135-3_2

RAPOSO, E. Case theory and Infl-to-Comp: The inflected infinitive in European Portuguese. Linguistic inquiry, MIT Press, v. 18, n. 1, p. 85109, 1987.

RAPOSO, E. Prepositional infinitival constructions in European Portuguese. In: JAEGGLI, O.; SAFIR, K. (Org.). The null subject parameter. Amsterdam: Springer, 1989. p. 277-305. https://doi. org/10.1007/978-94-009-2540-3_10

ROBERTS, I.; KATO, M. A. (Org.). Português brasileiro: uma viagem diacrônica. Campinas: Ed. da Unicamp, 1993.

RODRIGUES, C. Impoverished morphology and A-movement out of Case domains. Dissertation (Doctoral) - University of Maryland, College Park, 2004.

RODRIGUES, C. Agreement and Flotation in Partial and Inverse Partial Control Configurations. In: DUBINSKY, S.; DAVIES, W. (Org.). New Horizons in the Analysis of Control and Raising. Dordrecht: Springer, 2007. p. 213-229. https://doi.org/10.1007/978-1-4020-6176-9_9

RODRIGUES, C.; HORNSTEIN, N. Epicene Agreement and Inflected Infinitives When the Data Is "Under Control": A Reply to Modesto (2010). Syntax, Wiley Online Library, v. 16, p. 292-309, 2013.

ROSENBAUM, P. The Grammar of English Predicate Complement Constructions. Cambridge, MA: The MIT Press. 1967.

ROTHMAN, J.; DUARTE, I.; PIRES, A.; SANTOS, A. L. How early after all?: Inflected infinitives in European and Brazilian Portuguese L1 production. In: STAVRAKAKI, S.; LALIOTI, M.; KONSTATINOPOULOU, P. (Org.). Advances in Language Acquisition. Newcastle upon Tyne: Cambridge Scholars Publishing, 2013. 
SCIDA, E. The inflected infinitive in Romance Languages. New York: Routledge Taylor, 2004.

SCHERRE, M. P.; NARO, A. J. Mudança sem mudança: a concordância de número no português brasileiro. SCRIPTA, Belo Horizonte, PUC Minas, v. 18, p. 107-129, 2006.

SHEEHAN, M. Partial Control in Romance Languages: the covert comitative analysis. In: LAHOUSSE, K.; MARZO, S. (Org.). Romance Languages and Linguistic Theory. Amsterdam: John Benjamins, 2014. p. 181-198. https://doi.org/10.1075/rllt.6.09she

SHEEHAN, M. Partial pro-drop. In. A. GONÇALVES (Org.). Complement Clauses in Portuguese: Syntax and Acquisition. Amsterdam: John Benjamins, 2016. In press.

SIGURĐSSON, H. A. The Case of PRO. Natural Language and Linguistic Theory, Springer Link, v.26, p. 403-450, 2008.

SILVA NETO, S. da. Introdução ao estudo da língua portuguesa no Brasil. Rio de Janeiro: Ed. Presença, 1950.

SITARIDOU, I. The synchrony and diachrony of Romance Infinitives with nominative subjects. Dissertation (Doctoral) - University of Manchester, Manchester, UK, 2002.

SITARIDOU, I. Romance infinitives with subjects, subjunctive obviation and control theory. In: EUGUREN, L.; FERNÁNDEZ-SORIANO, O. (Org.). Coreference, modality, and Focus. Amsterdan: John Benjamins, 2007. p. 191-219. https://doi.org/10.1075/la.111.10sit

SUNDARESAN, S.; McFADDEN, T. Subject distribution in Tamil and other languages: selection vs. case. Journal of South Asian Languages, De Gruyter, v. 2, p. 5-34, 2009.

SUNDARESAN, S. Making sense of silence: finiteness and the (OC) pro vs. pro distinction. Natural Language and Linguistic Theory, Springer Link, v. 32, p. 59-85, 2014.

SZABOLCSI, A. Overt nominative subjects in infinitival complements: Data, diagnostics, and preliminary analyses. In: IRWIN, P.; MALDONADO, V. V. R. (Org.). Papers in syntax: NYU Working Papers in Linguistics. New York: New York University, 2009. v. 2, p. 1-55. 
TARALLO, F. On the alleged Creole origin of Brazilian Portuguese: untargeted syntactic change. Cadernos de Estudos Lingüísticos, Campinas, Unicamp, v. 15, p. 137-161, 1988.

TARALLO, F. Diagnosticando uma gramática brasileira: o português d'aquém e d'além mar ao final do século XIX. In: ROBERTS I.; KATO, M. A. (Org.). Português brasileiro: uma viagem diacrônica. Campinas: Editora da Unicamp. 1993. p. 69-105.

TROTZKE, A.; BADER, M.; FRAZIER, L. Third Factors and the Performance Interface in Language Design. Biolinguistics, Cyprus, University of Cyprus v.7, p. 1-34, 2013. Available at: <http://www. biolinguistics.eu>.

WURMBRAND, S. Restructuring cross-linguistically. In: NORTH EASTERN LINGUISTICS SOCIETY ANNUAL MEETING, 45., 2015, Amherst. BUI, T.; ÖZYILDIZ, D. (Org.). Proceedings... Amherst: University of Massachusetts, GLSA, 2015. p. 227-240. 